\title{
DISTRIBUTION OF PLOIDY LEVEL ON ADIANTUMDIAPHANUM BLUME AT VARIOUS ALTITUDES IN PROBOLINGGO
}

\author{
Ade Rezi Amelia ${ }^{1}$, Ahmad Fauzi*² \\ ${ }^{1}$ Program Studi Biologi, Fakultas Matematikadan Ilmu Pengetahuan Alam, \\ Universitas Negeri Malang \\ ${ }^{1}$ Program Studi Pendidikan Biologi, Fakultas Keguruan dan Ilmu Pendidikan, Universitas \\ Muhammadiyah Malang \\ email:ahmad_fauzi@umm.ac.id
}

Diterima : 03 November 2018. Disetujui: 20 November 2018. Dipublikasikan: 29 Desember 2018

\begin{abstract}
Abstrak
Paku-pakuan diindikasikan dapat menjadi organisme poliploid akibat pengaruh ketinggian tempat. Pada penelitian ini, kajian tentang persebaran tingkat ploidy A. Diaphanum Blume Blume atas dasar perbedaan ketinggian tempat dilakukan. Penelitian ini merupakan penelitian survey yang dilakukan di wilayah Kabupaten Probolinggo. Daerah Leces (50 mdpl), Lumbang (460 mdpl), dan Sukapura (820 mdpl) merupakan tiga wilayah pengambilan sampel penelitian yang secara berturut-turut mewakili daerah dataran rendah, sedang, dan tinggi. Penentuan tingkat ploidy dilakukan dengan menghitung jumlah kromosomsel-sel ujung akar. Hasil penelitian menunjukkan bahwa seluruh paku yang ditemukan di wilayah dataran sedang dan rendah merupakan individu diploid, sedangkan Adiantum yang ditemukan di wilayah dataran tinggi merupakan individu triploid. Penelitian ini mengindikasikan bahwa ketinggian tempat dapat meningkatkan level ploidy pada Adiantum.
\end{abstract}

Kata Kunci: Adiantum, altitud, level ploidy, poliploidi

\begin{abstract}
Ferns are indicated could become polyploid organism due to altitude effect. In this research, the distribution of ploidy level on AdiantumdiaphanumBlume based on difference altitude was studied. This study was a survey research conducted in Probolinggo Regency which aims studying the effect of altitude on ploidy level in A. diaphanumBlume. Leces (50 masl), Lumbang (460 masl), and Sukapura (820 masl) were the tree research sampling areas that represent low, medium, and highland location, respectively. The determination of ploidy level was conducted by counting the chromosome number of cells root tips. The results showed that all ferns found in the medium and lowland were diploid organisms, whereas all ferns found in the highlands were triploid organism.
\end{abstract}

Keywords: Adiantum, altitude, ploidy level, polyploidy

\section{INTRODUCTION}

Polyploidization is an important process during evolution process (Dar \& Rehman, 2017; Mason, 2016; Soltis \& Soltis, 2012). In high-level plants, the polyploidy phenomenon is a common occurrence (M. Hegarty et al., 2013; M. J. Hegarty \& Hiscock, 2008; Te Beest et al., 2012). The polyploidy phenomenon is considered as one of the mechanisms responsible for the speciation process (Y.-S. Chao, Liu, Chiang, \& Chiou, 2012; Madlung, 2013; Soltis \& Soltis, 2012; Wood et al., 2009). Moreover, polyploidy is considered as crucial event in the evolutionary process in Kingdom 
Plantae (Mason, 2016). This phenomenon causing an organism to have more than two sets of chromosomes and was formerly considered as the endpoint of the evolutionary process (Nico De Storme \& Geelen, 2013; Wood et al., 2009). However, after being studied and examined more deeply, the incidence of polyploidy was widely spread in natural populations until today (Ramsey \& Ramsey, 2014). Two groups of plants that have the largest proportion of polyploidy speciation are angiosperms and ferns (Y.-S. Chao et al., 2012; Dar \& Rehman, 2017; Fauzi, Corebima, \& Zubaidah, 2016; Fawcett $\&$ van de Peer, 2010; Wood et al., 2009).

Ferns are a group of vascular plants that reproduce through spores (Christenhusz \& Chase, 2014; Fernández, Kumar, \& Revilla, 2011; Mehltreter, Walker, \& Sharpe, 2010). This group of plants, that has the oldest lineage among other terrestrial plants, has a number of living species up to 13,271 species (Hassler, 2018; Vicent, Gabriel y Galán, \& Ainoüche, 2014). Various species of ferns live in various habitats, from wet to dry areas (Mehltreter et al., 2010; Ranker \& Haufler, 2008). The habitat of ferns are spread from the lowlands to the highlands and mountains (Nettesheim, Damasceno, \& Sylvestre, 2014; Salazar et al., 2015; Watkins \& Cardelús, 2009). In addition, all ferns do not have seeds or flowers and have two phases of life, gametophytes and sporophytes (Christenhusz \& Chase, 2014; Ranker \& Haufler, 2008).

Regarding the frequency of occurrence, the frequency of polyploidy in ferns group is greater than the angiosperm (Y.-S. Chao et al., 2012; Dar \& Rehman, 2017; Wood et al., 2009). Polyploidy in ferns can occur either spontaneously or due to errors during mitotic or meiotic division (Dar \& Rehman, 2017; Fernández, 2018). In the second cause, polyploidy occur due to the fusion of two gametes that have not been reduced. Usually, errors in meiotic division during sporogenesis produce diploid spores which cause the emergence of apogamous sporophytes (Y.-S. Chao et al., 2012; Fernández, 2018; Hernández, Andrada, De Los, Páez, \& Martínez, 2015). As a result, in both phases of life, ferns remain in diploid conditions (Fernández, 2018).

One popular genus of ferns is Adiantum. The species belonging to the Adiantum have a distinctive morphological appearance, such as the shape of the leaves which tend to be rounded and the stems are dark and shiny (Huiet et al., 2018). In general, Adiantum grows in a moist and shaded environment (Awathi, 2009). This genus has members up to 250 species (Christenhusz, Zhang, \& Schneider, 2011) and some of these species are found in Indonesia in various places with different altitudes (Hakim, Rahardi, \& Rachmansyah, 2018; Lestari, Adjie, Jaruwatanaphan, Watano, \& Pharmawati, 2014; Sukarsa, Apriliana, \& Chasanah, 2011; Trimanto \& Hapsari, 2016; Yusna, Sofiyanti, \& Fitmawati, 2016). The basic chromosome number of Adiantum species range from 29 to 30 chromosomes (Christenhusz \& Chase, 2014) and some of its members are polyploid organisms (F. H. Wang, Lu, Wen, Ebihara, \& Li, 2016).

Interestingly, research on ferns is still rare (Fernández, 2018). The reason, ferns are often regarded as a sideline members of Kingdom Plantae and many researchers were less interested in this group (Fernández et al., 2011). In fact, ferns have several characteristics, evolutionary history, and genetic conditions which is very interesting to always be studied. Beside that, even though ferns were reported to have high polyploidy frequencies, researches that studying the effect of altitudes on ploidy levels on ferns were still difficult to find. Furthermore, research studying this topic on Adiantum in Indonesia was still cannot be found. Moreover, studies of ploidy level on ferns in Indonesia were still rare and limited. Several studies that have been reported were the studies at Pterisvittata L. (Mumpuni, Chikmawati, \& Praptosuwiryo, 2015), 
Dryopterissparsa(Zubaidah, 2006), PterismultifidaPoir. (Hastuti, Praptosuwiryo, \& Djuita, 2011), and Adiantumraddianum(Perwati, 2009). All of these studies have not correlated the emergence of polyploid level to the altitudes of the ferns habitat.

With regard to Adiantum's place of life, these ferns can be found at various altitudes (A. H. Wang et al., 2017). In line with this, there is still no consistent tendency regarding the relationship of geographical patterns with the distribution of polyploid organisms (Weiss-Schneeweiss, Emadzade, Jang, \& Schneeweiss, 2013). However, some researchers have reported that elevation has the potential to influence ploidy levels in plants (Fauzi et al., 2016; Schinkel et al., 2016; Weiss-Schneeweiss et al., 2013). Researches that examine these phenomena still need to be carried out continuously to ensure the trends which predicted by previous researchers.

One of locations in Indonesia which its topographical consists of plains with various altitudes is Probolinggo. Temperatures in those various regions are also vary. The temperature ranges in the highlands, such as in BromoTenggerSemeru National Park and Sukapura, is around 5 to $18{ }^{\circ} \mathrm{C}$, while in moderate and lowland are $20^{\circ} \mathrm{C}-26^{\circ} \mathrm{C}$ and $25^{\circ} \mathrm{C}-32^{\circ} \mathrm{C}$, consecutively. Therefore, through observing chromosome number of $A$. diaphanmumBlume obtained from Probolinggo, the aim of this study was to determine whether there is any influence of altitudes on Adiantum'sploidy level or not.

\section{RESEARCH METHODS}

This study was survey research.The population of this research was all $A$. diaphanumBlume in Probolinggo, while the sample of this study were ferns obtained in Leces, Lumbang, and Sukapura. Leces (50 masl), Lumbang (460 masl), and Sukapura (820 masl) were represent low, moderate, and highland location, respectively (Figure 2). Altitude measurements was using altimeter. Sampling collection was carried out by taking Adiantum at each location and then planted it into polybags.

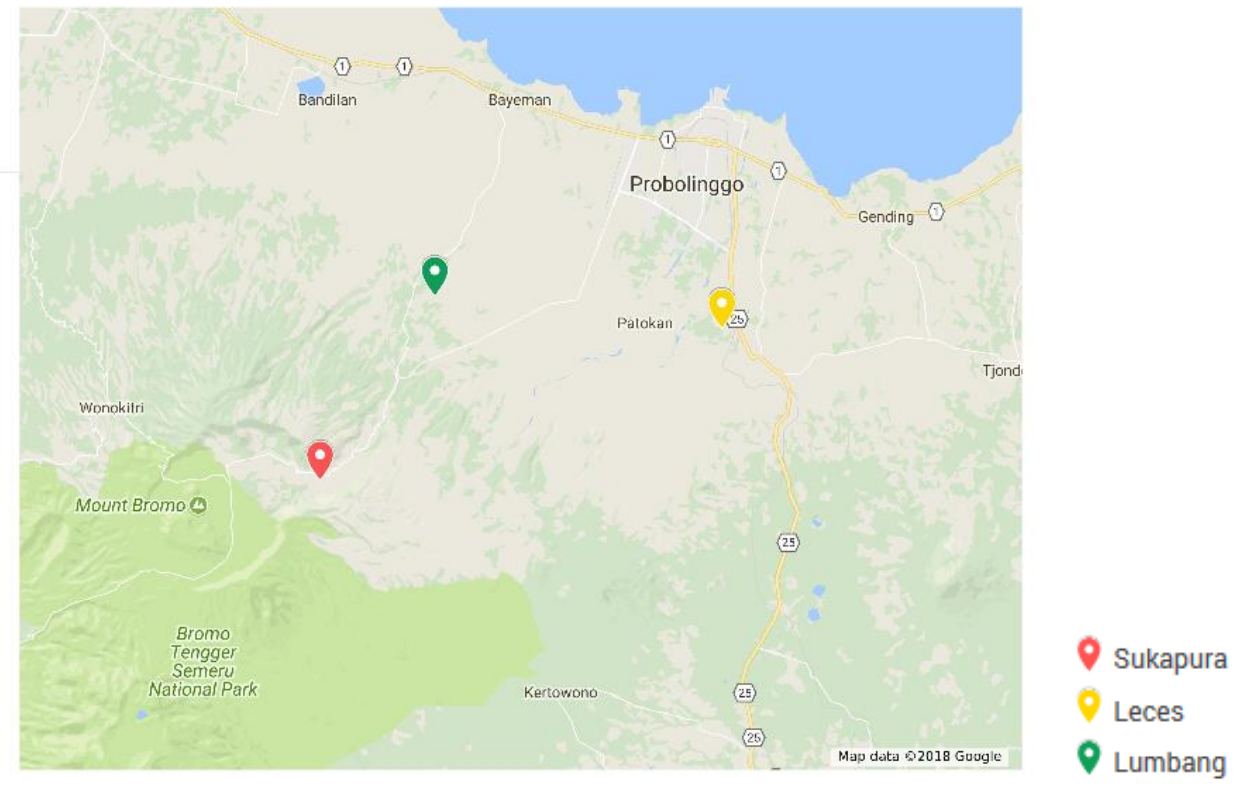

Figure 1. Location of research samples

The determination of ploidy level was conducted by the method described by Fauzi et al. (2016). The observation process was carried out at the Genetics Laboratory, 
UniversitasNegeri Malang. Adiantum root was cut $\pm 1 \mathrm{~cm}$ from the root cap at 9:00 a.m. After being washed with water, the fixation process using FAA solution was carried out on the root pieces. The maceration process was carried out by soaking the roots in $1 \mathrm{~N}$ $\mathrm{HCl}$ solution and stored in a waterbath at $60^{\circ} \mathrm{C}$ for 15 minutes. After the maceration process, the root cap was removed and the staining process was carried out on the object glass using acetocarmine. After 5 minutes of dyeing, the root pieces are covered with a cover glass and crushed with a cylindrical rod.

Ferns chromosomes were observed under a light microscope at 1000x magnification. The determination of ploidy level was conducted by calculating the chromosome number of cells that were undergoing metaphase or anaphase. Calculation of the chromosome number in one cell was repeated three times. The calculation of chromosome number was carried out as many as nine replications from each sampling area. The ploidy level in each fern was determined by dividing the number of observed chromosomes by the number of Adiantum base chromosomes, $x=30$ (Christenhusz \& Chase, 2014; Perwati, 2009). The data that has been collected were then analyzed using descriptive statistical analysis techniques, which used percentages.

\section{RESULTS AND DISCUSION}

Adiantum is one of the several fern genera found in Indonesia. In many regions in Indonesia, such as in Probolinggo, Adiantum species can be found either in low, moderate, or highland. As with other genera, fern species belonging to Adiantum can also be polyploid organisms. As a result, various Adiantum species with various ploidylevel could potentially be found in several locations, including in Probolinggo. Figure 2 presents a graph that informs the distribution of ploidy level of A. Diaphhanum Blume in three different altitudes which obtained in this study.

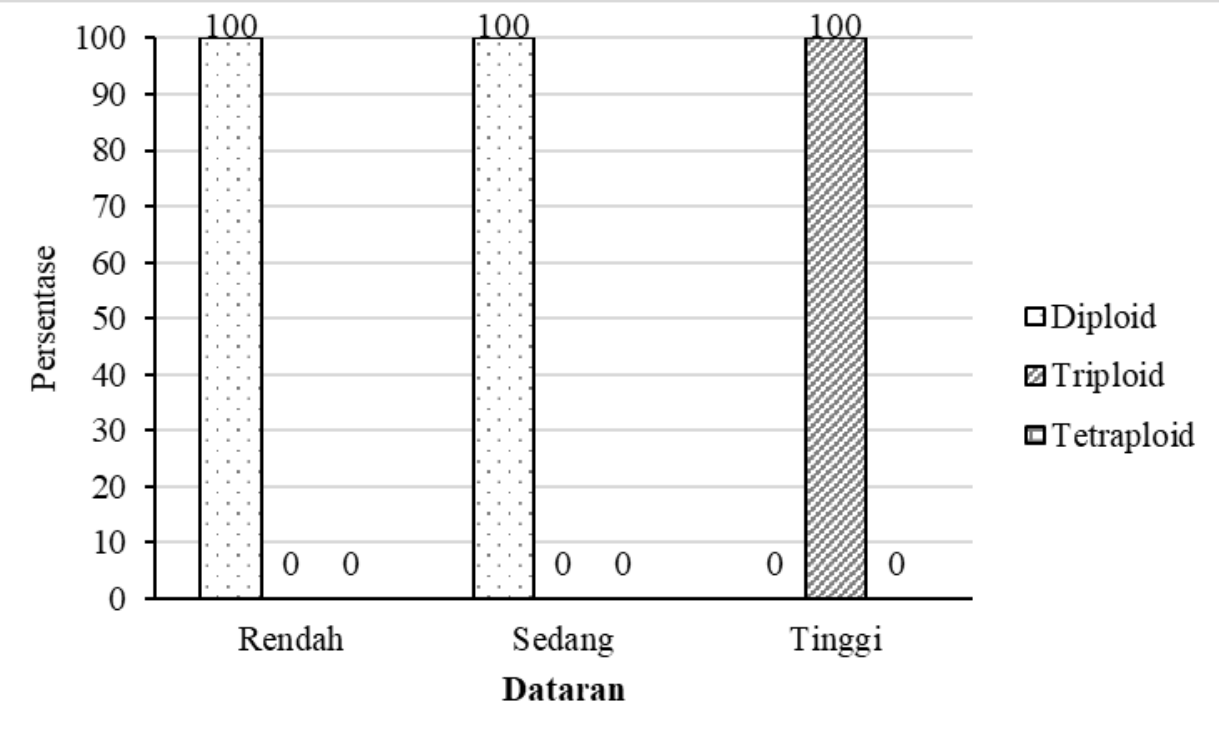

\section{Figure 2.Adiantumploidy level distribution graph based on different altitude in Probolinggo $(\mathbf{n}=9)$}

Based on Figure 2, it can be seen that polyploid fern could be found in Probolinggo. The existence of polyploid fern found in this study is in line with several previous studies that reported the presence of polyploid ferns in other locations. Some of these reports, for example, are reports that examined Pterisin Bogor (Hastuti et al., 
2011), some location in Java (Mumpuni et al., 2015), Vietnam until India (Y. Chao et al., 2012), and Taiwan (Y. Chao et al., 2012; Huang, Chou, Wang, \& Chiou, 2007). Polyploid ferns were also reported on Dryopteris in Batu(Zubaidah, 2006), Diplazium in Java (Praptosuwiryo \& Darnaedi, 2005); Botrychium in Switzerland, Sweden and the United States (Dauphin, Grant, \& Mraz, 2016); as well as Argyrochosmanivea in Argentina (Hernández et al., 2015). All of those studies have reported the presence of several natural polyploid ferns in the various locations being studied.

Figure 2 also presents an interesting finding from this study. Of the nine replications that have been observed, all Adiantum found in the moderate and lowlands were diploid organisms. On the other hand, $100 \%$ of Adiantum found in the highlands were triploid organisms. This finding shows that there was an effect of geographical location on ploidy levels. This finding is in line with Weiss-Schneeweiss's explanation (Weiss-Schneeweiss et al., 2013) which explains that polyploid organisms usually have geographical and/or ecological differences with diploid organisms. In addition, this finding is also in line with several other reports which indicate that altitude correlates with ploidy levels (Fauzi et al., 2016; Schinkel et al., 2016; Weiss-Schneeweiss et al., 2013). This result is also in line with Kirchheimer's explanation (Kirchheimer et al., 2016) which states that there is a shift in the niche between diploid and polyploid organisms that follows a decrease in environmental temperature.

Both highlands and mountains generally have colder temperatures than lower lands. The cold condition is known to trigger the formation of gametes whose chromosomes are not reduced (Bomblies, Higgins, \& Yant, 2015). The emergence of these gametes is caused by disruption of microtubule formation during meiosis and abnormalities during cytokinesis (N. De Storme, Copenhaver, \& Geelen, 2012). The existence of these gametes is a major cause of sexual polyploidization(Nico De Storme, Zamariola, Mau, Sharbel, \& Geelen, 2013).

Polyploid conditions in Adiantum also provide physiological benefits for these plants. Physiological ability to deal with conditions in the highlands will increase if the organism is a polyploid organism (Schinkel et al., 2016). In polyploid plants, photosynthesis rate will increase due to an increase in electron transport capacity (Coate et al., 2012).This ability provides benefits for plants in the highlands whose environmental conditions often have different levels of ultraviolet radiation and light intensity with moderate and lowland. In addition, genome multiplication in cells will generally cause an increase in the volume and surface area of the plant cell (Te Beest et al., 2012). These conditions may also have a positive impact on plants that live in the highlands.

This study also shows that $A$. diaphanumtetraploid cannot be found in Probolinggo. The absence of tetraploid organisms found in this study was not in lined with some previous studies. Mumpuni et al. (2015)has reported that the majority of polyploidy ferns that found in his study was tetraploid organism. Moreover, in other research, Zubaidah (2006) reported no triploid ferns found in his study. However, the findings of some other researchers are in line with the findings in this study. Some of these researchers, such as Hastuti et al. (2011) and Praptosuwiryo \& Darnaedi (2005) who reported that some species of ferns were found in triploid conditions.

The emergence of triploid ferns possibly due to a cross hybrid between diploid with tetraploid organisms (Hernández et al., 2015). If the presence of triploid organisms in this study were due to this such cross hybrid there is a possibility Adiantumtetraploid lived in that area. In connection with the existence of triploid organisms, the 
reproduction process that will be carried out by ferns will likely pass through apogamy. The reason is, without through apogamy, spores from triploid individuals will not have a balanced chromosome pair (Y.-S. Chao et al., 2012). The condition of the chromosomal imbalance will cause the spore to be unviable. This explanation is in line with Huang et al. (2007) which states reproduction through apogamy is closely related to ploidy level. In addition, the results of the study from Y.-S. Chao et al. (2012) also informed that all triploid ferns studied were reproduced through apogamy.

Regarding its distribution, this study informs that diploid organisms were found in two locations with different altitudes, while triploid organisms were only found in the highlands. Further studies are recommended to explore Adiantum in the Probolinggo with a wider sampling scale. These such study will confirm the spread of polyploid individuals when compared to diploids as well as also confirm the finding from Perwati (2009) who reported that polyploidsAdiantum have a wider distribution than diploid Adiantum. Such study has the potency to verify the results of this present study that could not find Adiantumtetraploid or with higher ploidy levels in Probolinggo.

\section{CONCLUSION}

In this study, differences in ploidy levels between $A$. diaphanumL. which grew in the low, medium and high altitudes were analyzed. Based on the results, triploid ferns could be found in the high altitude, while diploid ferns were found in the moderate and low altitudes. The results of this study indicate that altitude affects the ploidy level in $A$. diaphanumL.

Further research involving a wider sampling area is recommended. The results of such studies can confirm the results of this present study which reported that neither tetraploid nor higher ploidy level be found in the Probolinggo. Such research can also verify the absence of polyploid organisms in the moderate and low altitudes as reported in this present study.

\section{REFERENCES}

Awathi, D. K. (2009). Cryptogams (Algae, Bryophyta \& Pteridophyta). Meerut: Krishna Prakashan Media (P) Ltd.

Bomblies, K., Higgins, J. D., \& Yant, L. (2015). Meiosis evolves: Adaptation to external and internal environments. New Phytologist, 208(2), 306-323. https://doi.org/10.1111/nph.13499

Chao, Y.-S., Liu, H.-Y., Chiang, Y.-C., \& Chiou, W.-L. (2012). Polyploidy and Speciation in Pteris (Pteridaceae). Journal of Botany, 2012(March 2014), 1-7. https://doi.org/10.1155/2012/817920

Chao, Y., Chang, Y., Ngan, L. T., Truong, D. Van, Liu, H., \& Chiou, W. (2012). Different ploids of Pteris grevilleana Wall . ex Agardh var . ornata Alderw . ( Pteridaceae ) in Taiwan and Vietnam. Taiwania, 57(3), 278-282. Retrieved from http://tao.wordpedia.com/pdf_down.aspx?filename=JO00000236_57-3_278-282\&

Christenhusz, M. J. M., \& Chase, M. W. (2014). Trends and concepts in fern classification. Annals of Botany, 113(4), 571-594. https://doi.org/10.1093/aob/mct299

Christenhusz, M. J. M., Zhang, X. C., \& Schneider, H. (2011). A linear sequence of 
extant families and genera of lycophytes and ferns. Phytotaxa, 19, 7-54. https://doi.org/10.11646/phytotaxa.19.1.2

Coate, J. E., Luciano, A. K., Seralathan, V., Minchew, K. J., Owens, T. G., \& Doyle, J. J. (2012). Anatomical, biochemical, and photosynthetic responses to recent allopolyploidy in glycine dolichocarpa (fabaceae). American Journal of Botany, 99(1), 55-67. https://doi.org/10.3732/ajb.1100465

Dar, T.-U.-H., \& Rehman, R.-U. (2017). Polyploidy: Recent trends and future perspectives. New Delhi: Springer Pvt. Ltd. https://doi.org/10.1007/978-81-3223772-3

Dauphin, B., Grant, J., \& Mraz, P. (2016). Ploidy level and genome size variation in the homosporous ferns Botrychium s . 1 . ( Ophioglossaceae ). Plant Systematics and Evolution, 302(5), 575-584. https://doi.org/10.1007/s00606-016-1285-7

De Storme, N., Copenhaver, G. P., \& Geelen, D. (2012). Production of diploid male gametes in Arabidopsis by cold-induced destabilization of postmeiotic radial microtubule arrays. Plant Physiology, 160(4), 1808-1826. https://doi.org/10.1104/pp.112.208611

De Storme, N., \& Geelen, D. (2013). Sexual polyploidization in plants - cytological mechanisms and molecular regulation. New Phytologist, 198(3), 670-684. https://doi.org/10.1111/nph.12184

De Storme, N., Zamariola, L., Mau, M., Sharbel, T. F., \& Geelen, D. (2013). Volumebased pollen size analysis: An advanced method to assess somatic and gametophytic ploidy in flowering plants. Plant Reproduction, 26(2), 65-81. https://doi.org/10.1007/s00497-012-0209-0

Fauzi, A., Corebima, A. D., \& Zubaidah, S. (2016). The utilization of ferns as a model organism for studying natural polyploidization concept in genetics course. In International Conference on Education (pp. 51-58). Malang: Universitas Negeri Malang. Retrieved from http://pasca.um.ac.id/conferences/index.php/ice/article/download/11/8

Fawcett, J. A., \& van de Peer, Y. (2010). Angiosperm polyploids and their road to evolutionary success. Trends in Evolutionary Biology, 2(1), 16-21. https://doi.org/10.4081/eb.2010.e3

Fernández, H. (2018). Current advances in fern research. Cham: Springer International Publishing.

Fernández, H., Kumar, A., \& Revilla, M. A. (2011). Working with ferns. New York: Springer Science+Business Media.

Hakim, L., Rahardi, B., \& Rachmansyah, A. (2018). Checklist of flora along tourist trails to Mt. Lamongan, East Java (Indonesia): misconception of restoration and ecotourism programs in mountain region? Journal of Degraded and Mining Lands Management, 5(3), 1299-1305. https://doi.org/10.15243/jdmlm.2018.053.1299

Hassler, M. (2018). World ferns: Checklist of ferns and lycophytes of the world. In Y. Roskov, T. Orrell, D. Nicolson, N. Bailly, P. M. Kirk, T. Bourgoin, ... L. Penev (Eds.), Species 2000 \& ITIS catalogue of life. Leiden: Species 2000. Retrieved from http://www.catalogueoflife.org/col/details/database/id/140

Hastuti, D. V., Praptosuwiryo, T. N., \& Djuita, N. R. (2011). Sitologi dan tipe reproduksi Pteris multifida Poir. (Pteridaceae). Buletin Kebun Raya, 14(1), 8-18. Retrieved from https://media.neliti.com/media/publications/55517-ID-sitologi-dantipe-reproduksi-pteris-mult.pdf

Hegarty, M., Coate, J., Sherman-Broyles, S., Abbott, R., Hiscock, S., \& Doyle, J. (2013). Lessons from natural and artificial polyploids in higher plants. Cytogenetic and Genome Research, 140(2-4), 204-225. https://doi.org/10.1159/000353361

Hegarty, M. J., \& Hiscock, S. J. (2008). Genomic clues to the evolutionary success of 
polyploid plants. Current Biology, 18(10), R435-R444. https://doi.org/10.1016/j.cub.2008.03.043

Hernández, M. A., Andrada, A. R., De Los, V., Páez, A., \& Martínez, O. G. (2015). Ploidy level and obligate apogamy in two populations of Argyrochosma nivea var. tenera (Pteridaceae). Hoehnea, 42(1), 233-237. https://doi.org/10.1590/2236-8906$36 / 2014$

Huang, Y., Chou, H., Wang, J., \& Chiou, W. (2007). The distribution and habitats of the Pteris fauriei Complex in Taiwan. Taiwania, 52(1), 49-58. Retrieved from http://tai2.ntu.edu.tw/taiwania/pdf/tai.2007.52.49.pdf

Huiet, L., Li, F. W., Kao, T. T., Prado, J., Smith, A. R., Schuettpelz, E., \& Pryer, K. M. (2018). A worldwide phylogeny of Adiantum (Pteridaceae) reveals remarkable convergent evolution in leaf blade architecture. Taxon, 67(3), 488-502. https://doi.org/10.12705/673.3

Kirchheimer, B., Schinkel, C. C. F., Dellinger, A. S., Klatt, S., Moser, D., Winkler, M., ... Dullinger, S. (2016). A matter of scale: Apparent niche differentiation of diploid and tetraploid plants may depend on extent and grain of analysis. Journal of Biogeography, 43(4), 716-726. https://doi.org/10.1111/jbi.12663

Lestari, W. S., Adjie, B., Jaruwatanaphan, T., Watano, Y., \& Pharmawati, M. (2014). Molecular phylogeny of maidenhair fern genus Adiantum (Pteridaceae) from Lesses Sunda Islands Indonesia based on RBCL and TRNL-F. Reinwardtia, 14(1), 143-156. Retrieved from http://ejournal.biologi.lipi.go.id/index.php/reinwardtia/article/download/409/247

Madlung, A. (2013). Polyploidy and its effect on evolutionary success: Old questions revisited with new tools. Heredity, 110(2), 99-104. https://doi.org/10.1038/hdy.2012.79

Mason, A. S. (2016). Polyploidy and hybridization for crop improvement. Boca Raton: CRC Press. https://doi.org/10.15713/ins.mmj.3

Mehltreter, K., Walker, L. R., \& Sharpe, J. M. (2010). Fern ecology. Cambridge: Cambridge University Press.

Mumpuni, M., Chikmawati, T., \& Praptosuwiryo, T. N. (2015). Poliploidi intraspesifik Pteris vittata L. (Pteridaceae) di Pulau Jawa. Floribunda, 5(2), 53-59. Retrieved from http://www.ptti.or.id/journal/index.php/Floribunda/article/download/129/118

Nettesheim, F. C., Damasceno, E. R., \& Sylvestre, L. S. (2014). Different slopes of a mountain can determine the structure of ferns and lycophytes communities in a tropical forest of Brazil. Anais Da Academia Brasileira de Ciencias, 86(1), 199210. https://doi.org/10.1590/0001-3765201495912

Perwati, L. K. (2009). Analisis derajat ploidi dan pengaruhnya terhadap variasi ukuran stomata dan spora pada Adiantum raddianum. Bioma, 11(2), 39-44. Retrieved from https://core.ac.uk/download/pdf/11718276.pdf

Praptosuwiryo, T. N., \& Darnaedi, D. (2005). Cytological study of some species of ferns genus Diplazium in Java II. Floribunda, 2(8), 209-221. Retrieved from https://kulslide.com/downloadFile/59fe8fdbd64ab2f10511f73c

Ramsey, J., \& Ramsey, T. S. (2014). Ecological studies of polyploidy in the 100 years following its discovery. Philosophical Transactions of the Royal Society B: Biological Sciences, 369(1648), 15-19. https://doi.org/10.1098/rstb.2013.0352

Ranker, T. A., \& Haufler, C. H. (2008). Biology and evolution of ferns and lycophytes. Cambridge: Cambridge University Press. https://doi.org/10.15713/ins.mmj.3

Salazar, L., Homeier, J., Kessler, M., Abrahamczyk, S., Lehnert, M., Krömer, T., \& Kluge, J. (2015). Diversity patterns of ferns along elevational gradients in Andean tropical forests. Plant Ecology and Diversity, 8(1), 13-24. https://doi.org/10.1080/17550874.2013.843036 
Schinkel, C. C. F., Kirchheimer, B., Dellinger, A. S., Klatt, S., Winkler, M., Dullinger, S., \& Hörandl, E. (2016). Correlations of polyploidy and apomixis with elevation and associated environmental gradients in an alpine plant. AoB Plants, 8(August), plw064. https://doi.org/10.1093/aobpla/plw064

Soltis, P. S., \& Soltis, D. E. (2012). Polyploidy and genome evolution. Berlin: SpringerVerlag. https://doi.org/10.15713/ins.mmj.3

Sukarsa, S., Apriliana, H., \& Chasanah, T. (2011). Diversitas species tumbuhan Paku hias dalam upaya melestarikan sumberdaya hayati Kebun Raya Baturraden. Biosfera, 28(1), 23-31. Retrieved from https://journal.bio.unsoed.ac.id/index.php/biosfera/article/download/257/207

Te Beest, M., Le Roux, J. J., Richardson, D. M., Brysting, A. K., Suda, J., Kubešová, M., \& Pyšek, P. (2012). The more the better? The role of polyploidy in facilitating plant invasions. Annals of Botany, 109(1), 19-45. https://doi.org/10.1093/aob/mcr277

Trimanto, T., \& Hapsari, L. (2016). Botanical survey in thirteen montane forests of Bawean Island Nature Reserve, East Java Indonesia: Flora diversity, conservation status, and bioprospecting. Biodiversitas, Journal of Biological Diversity, 17(2), 832-846. https://doi.org/10.13057/biodiv/d170261

Vicent, M., Gabriel y Galán, J. M., \& Ainoüche, A. (2014). Insight into fern evolution: A mechanistic approach to main concepts and study techniques. Botanica Complutensis, 38, 7-24. https://doi.org/10.5209/rev_BOCM.2014.v38.45771

Wang, A. H., Wang, F. G., Zhang, W. W., Ma, X. D., Li, X. W., Yi, Q. F., ... Xing, F. W. (2017). Revision of series Gravesiana (Adiantum L.) based on morphological characteristics, spores and phylogenetic analyses. PLOS ONE, 12(4), e0172729. https://doi.org/10.1371/journal.pone.0172729

Wang, F. H., Lu, J. M., Wen, J., Ebihara, A., \& Li, D. Z. (2016). Applying DNA barcodes to identify closely related species of ferns: A case study of the Chinese Adiantum (Pteridaceae). PLoS ONE, 11(9), 1-21. https://doi.org/10.1371/journal.pone.0160611

Watkins, J. E., \& Cardelús, C. (2009). Habitat differentiation of ferns in a lowland tropical rain forest. American Fern Journal, 99(3), 162-175. https://doi.org/10.1640/0002-8444-99.3.162

Weiss-Schneeweiss, H., Emadzade, K., Jang, T. S., \& Schneeweiss, G. M. (2013). Evolutionary consequences, constraints and potential of polyploidy in plants. Cytogenetic and Genome Research, 140(2-4), 137-150. https://doi.org/10.1159/000351727

Wood, T. E., Takebayashi, N., Barker, M. S., Mayrose, I., Greenspoon, P. B., \& Rieseberg, L. H. (2009). The frequency of polyploid speciation in vascular plants. Proceedings of the National Academy of Sciences, 106(33), 13875-13879. https://doi.org/10.1073/pnas.0811575106

Yusna, M., Sofiyanti, N., \& Fitmawati. (2016). Keanekaragaman pteridaceae berdasarkan karakter morfologi dan fitokimia di hutan PT . Chevron Pacific Indonesia ( PT . CPI ) Rumbai. Jurnal Riau Biologia, 1(2), 165-172. Retrieved from https://ejournal.unri.ac.id/index.php/JRB/article/download/3778/3681

Zubaidah, S. (2006). Tingkat ploidi dan tipe reproduksi Dryopteris sparsa di Hutan Wisata Cangar Kotatif Batu Jawa Timur. Berk. Penel. Hayati, 11, 113-117. Retrieved from https://berkalahayati.org/files/journals/1/articles/492/submission/492-1623-1SM.pdf 